\title{
Genome-wide Association Study Identifies 2 New Loci Associated With Anti-NMDAR Encephalitis
}

Anja K. Tietz, MSc, Klemens Angstwurm, MD, Tobias Baumgartner, MD, Kathrin Doppler, MD, Katharina Eisenhut, MD, Martin Elisak, MD, Andre Franke, PhD, Kristin S. Golombeck, MD, Robert Handreka, Max Kaufmann, MD, Markus Kraemer, MD, Andrea Kraft, MD, Jan Lewerenz, MD, Wolfgang Lieb, MD, Marie Madlener, MD, Nico Melzer, MD, Hana Mojzisova, MD, Peter Möller, MD, Thomas Pfefferkorn, MD, Harald Prüss, MD, Kevin Rostásy, MD, Margret Schnegelsberg, MD, Ina Schröder, Kai Siebenbrodt, MD, Kurt-Wolfram Sühs, MD, Jonathan Wickel, MD, Klaus-Peter Wandinger, MD, Frank Leypoldt, MD, and Gregor Kuhlenbäumer, MD, PhD, on behalf of the German Network for Research on Autoimmune Encephalitis (GENERATE)

Neurol Neuroimmunol Neuroinflamm 2021;8:e1085. doi:10.1212/NXI.0000000000001085

\section{Abstract}

\section{Background and Objectives}

To investigate the genetic determinants of the most common type of antibody-mediated autoimmune encephalitis, anti-NMDA receptor (anti-NMDAR) encephalitis.

\section{Methods}

We performed a genome-wide association study in 178 patients with anti-NMDAR encephalitis and 590 healthy controls, followed by a colocalization analysis to identify putatively causal genes.

\section{Results}

We identified 2 independent risk loci harboring genome-wide significant variants $\left(p<5 \times 10^{-8}\right.$, OR $\geq 2.2$ ), 1 on chromosome 15 , harboring only the LRRK1 gene, and 1 on chromosome 11 centered on the ACP2 and NR1H3 genes in a larger region of high linkage disequilibrium. Colocalization signals with expression quantitative trait loci for different brain regions and immune cell types suggested $A C P 2, N R 1 H 3, M A D D, D D B 2$, and $C 11$ orf 49 as putatively causal genes. The best candidate genes in each region are $L R R K 1$, encoding leucine-rich repeat kinase 1 , a protein involved in B-cell development, and NR1H3 liver X receptor alpha, a transcription factor whose activation inhibits inflammatory processes.

\section{Discussion}

This study provides evidence for relevant genetic determinants of antibody-mediated autoimmune encephalitides outside the human leukocyte antigen (HLA) region. The results suggest that future studies with larger sample sizes will successfully identify additional genetic determinants and contribute to the elucidation of the pathomechanism.

\author{
Correspondence \\ Dr. Kuhlenbäumer \\ g.kuhlenbaeumer@ \\ neurologie.uni-kiel.de
} From the Department of Neurology (A.K.T., F.L., G.K.), Kiel University; Department of Neurology (K.A.), University Hospital Regensburg; Department of Epileptiology (T.B.), University
Hospital Bonn; Department of Neurology (K.D.), University Hospital Würzburg; Institute of Clinical Neuroimmunology (K.E.), Biomedical Center and University Hospital, Ludwig
Maximilians University, Munich, Germany; Department of Neurology (M.E., H.M.), Charles University, Second Faculty of Medicine and Motol University Hospital, Prague, Czech
Republic; Institute of Clinical Molecular Biology (A.F.), Kiel University; Department of Neurology (K.S.G.), University Hospital Münster; Department of Neurology (R.H.), Carl-Thiem-
Klinikum Cottbus; Institute of Neuroimmunology and Multiple Sclerosis (INIMS) (Max Kaufmann), University Medical Center Hamburg-Eppendorf; Department of Neurology (Markus
Kraemer), Alfried Krupp Hospital, Essen; Department of Neurology (Markus Kraemer, N.M.), Medical Faculty, Heinrich-Heine University Düsseldorf; Department of Neurology (A.K.),
Martha-Maria Hospital Halle; Department of Neurology (J.L.), University of Ulm; Institute of Epidemiology (W.L.), Kiel University; Department of Neurology (M.M.), University Hospital
Cologne; Department of Neurology and Clinical Neurophysiology (P.M.), Klinikum Weimar; Department of Neurology (T.P.), Klinikum Ingolstadt; Department of Neurology and
Experimental Neurology (H.P.), Charité - Universitätsmedizin Berlin and German Center for Neurodegenerative Diseases (DZNE) Berlin; Department of Pediatric Neurology (K.R.),
Children's Hospital Datteln, Witten/Herdecke University; Department of Neurology (M.S.), Asklepios Hospitals Schildautal, Seesen; Neuroimmunology (I.S., K.-P.W., F.L.), Institute of
Clinical Chemistry, University Hospital Schleswig-Holstein, Kiel/Lübeck; Epilepsy Center Frankfurt Rhine-Main and Department of Neurology (K.S.), Unversity Hospital and Goethe
Universiy Frankfurt; Department of Neurology (K.-W.S.), Hannover Medical School; and Section Translational Neuroimmunology (J.W.), Department of Neurology, University Hospital
Jena, Germany.

Go to Neurology.org/NN for full disclosures. Funding information is provided the end of the article.

German Network for Research on Autoimmune Encephalitis (GENERATE) coinvestigators are listed in Appendix 2 at links.Iww.com/NXI/A587.

The Article Processing Charge was funded by BMBF via UKSH Kiel.

This is an open access article distributed under the terms of the Creative Commons Attribution-NonCommercial-NoDerivatives License 4.0 (CC BY-NC-ND), which permits downloading and sharing the work provided it is properly cited. The work cannot be changed in any way or used commercially without permission from the journal. 


\section{Glossary}

AAO $=$ age at onset; $\mathbf{e Q T L}=$ expression quantitative trait loci; GENERATE $=$ German Network for Research on Autoimmune Encephalitis; GSA = global screening array; GT = genotyped; GTEx = Genotype-Tissue Expression; GWAS = genome-wide association study; HLA = human leukocyte antigen; HSV-1 = herpes simplex virus type 1 (HSV-1); HWE = Hardy-Weinberg equilibrium; IBD = identity by descent; IM = imputed; IgG = immunoglobulin G; LD = linkage disequilibrium; LDSC = LD score regression; $\mathbf{L X R} \boldsymbol{a}=$ liver $\mathrm{X}$ receptor alpha; $\mathbf{M A D D}=$ mitogen-activated protein kinase activating death domain; $\mathrm{MAF}=$ minor allele frequency; $\mathbf{M A P}=$ mitogen-activated protein; NMDAR = NMDA receptor; $\mathbf{P C}=$ principal component; $\mathbf{P P}=$ posterior probability; SNP = single nucleotide polymorphism; TNF- $\boldsymbol{a}=$ tumor necrosis factor alpha; TOPmed $=$ Trans-Omics for Precision medicine.

Antibody-mediated encephalitides are a recently discovered group of rare diseases caused by autoantibodies against CNS system antigens. ${ }^{1}$ Subgroups are defined by the respective target antigens. The most common subgroup is caused by immunoglobulin $\mathrm{G}(\mathrm{IgG})$ class antibodies against the GluN1 subunit of the NMDA receptor (NMDAR), the most important excitatory neurotransmitter in the CNS. NMDAR antibodies cause internalization of surface NMDAR, thereby reducing signal transduction. Anti-NMDAR encephalitis affects children and adults with a female preponderance. The estimated prevalence is $0.6 / 100,000$ population. ${ }^{2}$ It manifests with behavioral changes, psychiatric symptoms, epileptic seizures, memory dysfunction, movement disorders, and loss of consciousness and often responds favorably to immunotherapy. ${ }^{3} \mathrm{~A}$ definite diagnosis requires the detection of antiNMDAR antibodies of the IgG class in serum and/or CSF. Known trigger factors include ovarian teratomas with ectopic expression of NMDAR and viral (mostly herpes simplex virus type 1 [HSV-1]) encephalitis. ${ }^{1}$ In a first genome-wide association study (GWAS) of antibody-mediated encephalitides in a much smaller sample, we found no variants showing genome-wide significant association with anti-NMDAR encephalitis. ${ }^{4}$ For this study, we doubled the sample size, modified the analysis parameters, and added colocalization analysis to identify putatively causal genes.

\section{Methods}

\section{Study Population}

In this case-control study, we analyzed 212 samples from patients with NMDAR antibodies (197 German and 15 Czech patients) collected in the years 2015-2020. AntiNMDAR encephalitis was classified according to consensus criteria based on a compatible clinical syndrome together with detection of IgG-NMDAR antibodies in serum and/or CSF. ${ }^{3}$ One hundred seven patients were already included in our previous GWAS. ${ }^{4}$ The additional 105 individuals were either recruited via the German Network for Research on Autoimmune Encephalitis (GENERATE, $\mathrm{n}=80$ ) or specifically for this study $(n=25)$. For patient recruitment, we contacted the centers of the GENERATE network as well as other neurologic departments caring for patients with antibody-mediated encephalitides. All contributing scientists are listed in
eTable 1, links.lww.com/NXI/A587. Healthy control samples ( $\mathrm{n}=1,219)$ were obtained from the PopGen study, a population-based biobank from northern Germany. ${ }^{5,6}$

\section{Genotyping}

Genomic DNA was isolated from blood $(\mathrm{n}=150)$ or saliva $(n=62)$ using standard procedures. The samples were genotyped in 3 batches at the Institute of Clinical Molecular Biology, Kiel University on Infinium Global Screening Array (GSA; Illumina). Array version 2.0 was used for cases and version 1.0 for healthy controls. Genotypes were called using Illumina GenomeStudio 2.0 according to the manufacturer's instructions using in-house clusterfiles. We previously determined a $>99.8 \%$ genotype concordance for DNA isolated from blood and saliva genotyped on the GSA array in 8 individuals.

\section{Quality Control and Imputation}

We used PLINK v.1.9, ${ }^{7}$ R v.3.6.3, ${ }^{8}$ and the Illumina GenomeStudio for genotype quality control. First, we excluded all nonoverlapping variants between the 2 different versions of the GSA chip, variants with multicharacter allele codes, insertions, deletions, duplicated markers, and ambiguous $\mathrm{A} / \mathrm{T}$ and $\mathrm{G} / \mathrm{C}$ variants. We determined genotyping sex by the X-chromosome inbreeding coefficients, with $\mathrm{F}<0.2$ being female and $\mathrm{F}>0.8$ being male, and excluded samples with discordance between reported and imputed sex. After that, we filtered first variants and then individuals with a relaxed threshold for a call rate of less than $85 \%$, followed by a stringent threshold of $98 \%$. We applied a minor allele frequency (MAF) filter of $1 \%$, as well as filters for significant deviation from Hardy-Weinberg equilibrium (HWE; $p<1 \times$ $\left.10^{-6}\right)$ in controls, informative missingness $\left(p<1 \times 10^{-5}\right)$, and outlying heterozygosity rate (mean \pm 3 SDs). To determine duplicated or cryptically related individuals, we used pairwise genome-wide estimates of the proportion of identity by descent (IBD) on a pruned data set containing only markers in low linkage disequilibrium $(\mathrm{LD})$ regions (pairwise $\mathrm{r}^{2}<0.2$ ) and excluded those more closely related than third-degree relatives (IBD > 0.125). Of each identified sample pair, we kept the individual with a higher call rate. To identify ethnic outliers, we used a procedure similar to the one suggested in the $\mathrm{R}$ package plinkQ $\mathrm{C}^{9}$ : we combined the genotype data with the samples of the publicly available 1000 Genomes 
Project ${ }^{10}$ and performed a principal component (PC) analysis on the merged data set. A European center was determined by the first 2 PCs of known European samples, and the Euclidean distance from this center determined the ethnical assignment with samples more than 1.5 times the maximal European Euclidean distance away from the center being excluded. The remaining individuals were used for preliminary association analysis based on which we visually inspected the cluster plots of all variants with a $p$ value $<10^{-4}$ and discarded variants without adequate cluster separation. To overcome issues with population stratification, we matched controls by ancestry and sex to cases with the R package PCAmatchR, ${ }^{11}$ leading to 590 control samples for the analysis and approximately 3 controls per case. An exact match on sex was used because there were significantly more female samples in the case samples than in the control samples.

Imputation was performed on the quality-assured data set, containing 768 individuals (590 controls and 178 cases) and 446,353 variants. Subsequently, 26,356,529 variants were imputed based on the Trans-Omics for Precision Medicine (TOPmed) r2 panel $^{12}$ using the TOPMed Imputation Server, ${ }^{13}$ which uses (mini Markov-chain haplotyper 4) for imputation. ${ }^{14} \mathrm{~A}$ quality check was performed, including variants with an MAF $>1 \%$, an imputation quality score $\mathrm{R}^{2}>0.7$, and no significant deviation from HWE $\left(p<1 \times 10^{-6}\right)$ in controls, resulting in $8,073,349$ variants.

\section{Association Analysis}

We conducted an association analysis on the whole data set using a genome-wide significance threshold of $p<5 \times 10^{-8}$. We applied an additive logistic regression model, including sex and PCs, to estimate the association of each single nucleotide polymorphism (SNP) with the disease status. The number of PCs was chosen using scree plot analysis. ${ }^{15}$ Population stratification was examined using the inflation factor $\lambda$ and the visual inspection of quantile-quantile plots. To further distinguish between confounding factors like population stratification and polygenicity of the anti-NMDAR encephalitis trait, we performed LD score regression (LDSC) using the LDHub web interface. ${ }^{16}$ Conditional analyses in which successively each genome-wide significant variant was included as a covariate were conducted to identify adjacent independent signals. We used 7,122 genotyped and quality controlled variants from the human major histocompatibility complex region on chromosome 6 to impute four-digit human leukocyte antigen (HLA) alleles using the R package HLA imputation using attribute bagging. ${ }^{17}$ It uses attribute bagging to impute genotypes, and we chose a prediction model specifically for European ancestry and the Illumina GSA chip. We performed the association analysis with python $\mathrm{HLA}^{18}$ using an additive, logistic model including sex and the first $\mathrm{PC}$ as covariates and adjusted $p$ values with the Benjamini-Hochberg false discovery rate step-up method.

To examine the origin of the variant-trait association signals more closely, we analyzed the subsamples of patients with early/late disease onset (< or $\geq 25$ years) and patients with/ without a tumor. To prioritize genes putatively involved in the disease etiology, we investigated the overlap of expression quantitative trait loci (eQTL) from the Genotype-Tissue Expression (GTEx) project ${ }^{19}$ as well as immune cell eQTL from the BLUEPRINT (A BLUEPRINT of haematopoietic epigenomes) project ${ }^{20}$ and variants in the risk loci identified by this GWAS. We investigated whether these 2 independent signals might stem from the same causal variant by colocalization analysis conducted with coloc. ${ }^{21}$ Coloc uses approximate Bayes factors to estimate posterior probabilities (PP) for common variants causal in the GWAS as well as the eQTL study. We studied all variants present in the GWAS results as well as in GTEx V7 for the 13 available brain tissues or present in the BLUEPRINT immune cell eQTL data within $100 \mathrm{~kb}$ up- and downstream of each gene in the 2 encephalitis risk loci. Coloc estimates PPs for 4 different scenarios. PP4 denotes the posterior probability that both traits-the disease association and the eQTL_-are caused by the same variant. A PP4 over $70 \%$ was considered as evidence for colocalization. We used LocusZoom ${ }^{22}$ and $\mathrm{R}$ to visualize the association results. All analyses and the presentation of the results in this article are based on the human genome version 38 (GRCh38/ hg38).

\section{Standard Protocol Approvals, Registrations, and Patient Consents}

All participants gave written informed consent. Institutional review board approval was obtained from the ethical advisory boards of the Universities of Kiel and Luebeck (B337/13; 13-162).

\section{Data Availability}

Summary level genetic data for all variants with $p$ values $<1 \times$ $10^{-4}$ are available from the corresponding author on reasonable request to any qualified investigator.

\section{Results}

Table 1 summarizes the clinical features of patients and control individuals demonstrating that patients included in our first $\mathrm{GWAS}^{4}$ are comparable to the additional patients in this study regarding age, sex, and clinical features. However, the control individuals were much older than the patients. Genotype data for 212 individuals with anti-NMDAR encephalitis and 1,219 controls were available for analysis. After quality control procedures and control matching, 178 cases and 590 healthy controls remained (eTable 2, links.lww.com/ NXI/A588). Imputation resulted in 8,073,349 quality-assured variants with an MAF > $1 \%$. We incorporated sex and the first dimension of the PC analysis as indicated by scree plot analysis as covariates. In contrast to our first GWAS of antiNMDAR encephalitis, we did not include age as a covariate (for rationale, see Discussion). The genomic inflation factor of $\lambda=1.03$ indicated a low degree of population stratification (Figure 1A). The LDSC intercept was 1.01 (standard error = 
Table 1 Sample Characteristics

\begin{tabular}{|c|c|c|c|c|}
\hline & Patients from first GWAS ${ }^{4}$ & New patients in this GWAS & Combined patient sample & Control individuals \\
\hline Number & 91 & 87 & 178 & 590 \\
\hline$\%$ Female & $82.4 \%$ & $72.4 \%$ & $77.5 \%$ & $70.7 \%$ \\
\hline Mean AAO (cases)/age (controls) $( \pm S D)$ & $23.5( \pm 13.3)$ & $29.5( \pm 19.4)$ & $25( \pm 16.7)$ & $57( \pm 14.6)$ \\
\hline Tumor & $15.7 \%$ (93\% teratoma) & $17.1 \%$ (85\% teratoma) & $16.4 \%$ (89\% teratoma) & NA \\
\hline Prodromal symptoms ${ }^{a}$ & $38.3 \%$ & $43.1 \%$ & $40.5 \%$ & NA \\
\hline Epileptic seizures $^{a}$ & $69.6 \%$ & $52.8 \%$ & $62.9 \%$ & NA \\
\hline Psychiatric symptoms ${ }^{a}$ & $95.1 \%$ & $71.7 \%$ & $85.8 \%$ & NA \\
\hline Movement disorders $^{a}$ & $46.1 \%$ & $26.4 \%$ & $38.0 \%$ & NA \\
\hline Autonomic dysfunction $^{a}$ & $38.9 \%$ & $31.4 \%$ & $35.8 \%$ & NA \\
\hline Abnormal EEG ${ }^{a}$ & $69.6 \%$ & $67.4 \%$ & $68.7 \%$ & NA \\
\hline Abnormal MRI ${ }^{\mathrm{a}}$ & $55.7 \%$ & $42.0 \%$ & $50.4 \%$ & NA \\
\hline CSF Pleocytosis $^{a}$ & $73.2 \%$ & $71.4 \%$ & $72.5 \%$ & NA \\
\hline Oligoclonal bands ${ }^{a}$ & $67.8 \%$ & $69.2 \%$ & $68.4 \%$ & NA \\
\hline
\end{tabular}

Abbreviations: AAO = age at onset; GENERATE = German Network for Research on Autoimmune Encephalitis; GWAS = genome-wide association study; NA = not applicable.

Descriptive statistics for the overall patient sample, for patients from the first GWAS, ${ }^{4}$ for newly recruited patients, and for healthy control individuals.

a Only available for GENERATE samples.

0.01 ), with $44 \%$ of the genomic inflation attributable to confounding bias including population stratification and cryptic relatedness. This indicates that the majority of inflation is caused by polygenicity. We found 13 genetic variants in 2 distinct loci below the threshold of $p=5 \times 10^{-8}$ for genome-wide significance (Figure 1, B-D, Table 2), with leading variants rs 10902588 on chromosome $15(\mathrm{OR}=2.24$ [95\% CI $\left.=1.70-2.95], p=1.78 \times 10^{-8}\right)$ and $\mathrm{rs} 75393320$ on chromosome $11\left(\mathrm{OR}=2.20[1.66-2.92], p=3.78 \times 10^{-8}\right)$ as well as only $14 \mathrm{~Kb}$ further downstream rs 11039155 with the same $p$ value and OR. Conditional analysis including the top variants at each locus argues against the presence of any independent secondary signals (eFigure 1, links.lww.com/NXI/ A586). The significant variants on chromosome 15 are located in the leucine rich repeat region 1 (LRRK2) gene. In the chromosome 11 locus, rs75393320 lies in the lysosomal acid phosphatase 2 (ACP2) gene, and rs 11039155 is located in the nuclear receptor subfamily 1 group $\mathrm{H}$ member 3 (NR1H3) gene.

Additional analyses of subpopulations defined by tumor status and age at onset yielded no genome-wide significant associations. In the previous GWAS, we observed a weak association between patients with anti-NMDAR encephalitis and the HLA-B*07:02 allele, preferentially in the patients with late disease onset. We did not confirm this association in the current GWAS. We were not able to analyze the recently reported association with HLA-DRB $1^{*} 16: 02$ in a Chinese population ${ }^{23}$ because the frequency of this allele is very low in the German population and no patient in our sample and only
1 control individual carried this allele. We did not detect any novel significant HLA associations. We performed an additional analysis, splitting the patient sample into the samples already included in our prior GWAS $^{4}$ and the newly acquired samples only (eTable 3, links.lww.com/NXI/A589). For all genome-wide significant variants in the complete sample, we found an identical direction and comparable magnitude of the ORs as well as $p$ values between $1.37 \times 10^{-7}$ and $1.13 \times 10^{-3}$ demonstrating that both subsamples contributed to the final result. As readily apparent in Figure 1C, the significant variants on chromosome 11 are located in a gene-rich area with numerous further variants in high LD with the leading variant and $p$ values less than $1 \times 10^{-5}$. Coloc analysis showed colocalization with a PP4 $>0.7$ between the sum of GWAS variants and GTEx eQTLs for the 3 genes NR1H3, ACP2, and mitogen-activated protein (MAP) kinase activating death domain $(M A D D)$ on chromosome 11 in brain tissues (Figure 2) and for the 4 genes NR1H3, ACP2, damagespecific DNA binding protein 2 (DDB2), and chromosome 11 open reading frame 49 (C11orf49) in various immune cells (Figure 3 ). We did not identify any single variant with a PP4 $>0.7$. In contrast, we found no colocalizing eQTL signals for the GWAS signal on chromosome 15.

\section{Discussion}

Except for the HLA complex, the genetic determinants of antibody-mediated encephalitides are unknown. The collection of sufficiently large sample sizes for genetic analyses is 
A

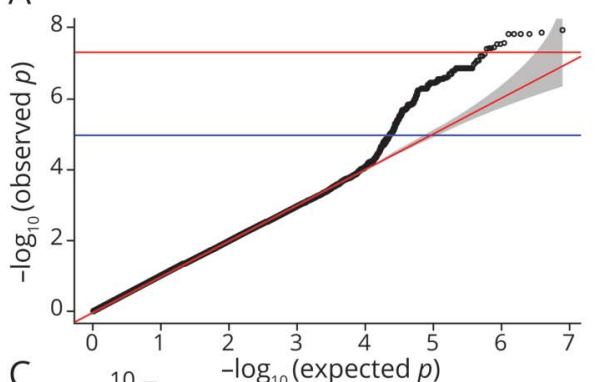

C

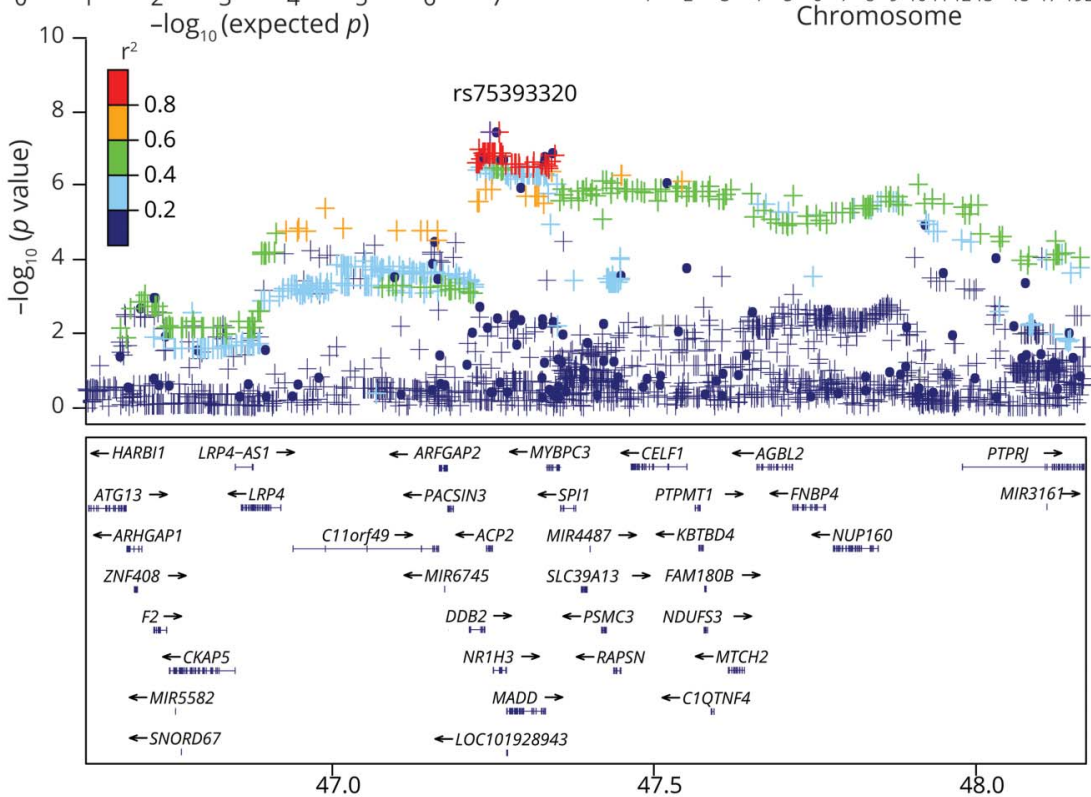

D

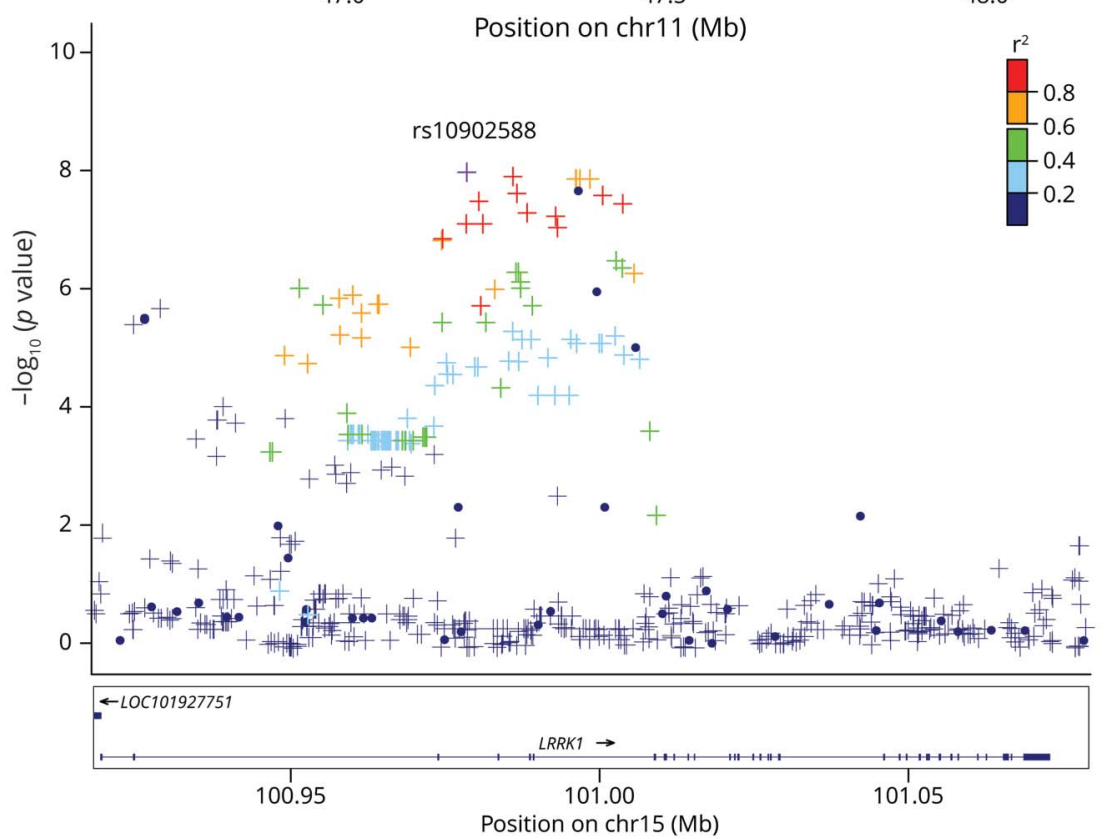

B

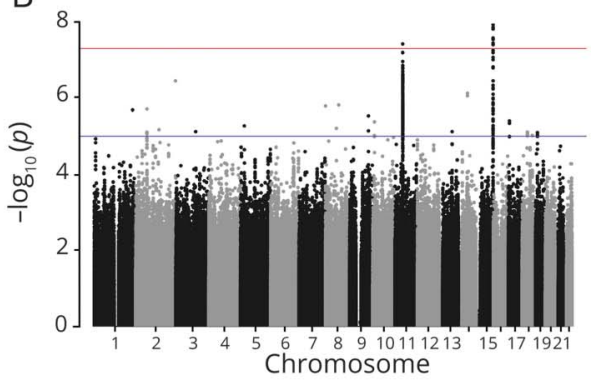

(A) Quantile-quantile plot of association analysis for $8,073,349$ variants. The plot shows deviation from the null distribution in the upper tail, which corresponds to variants with the strongest evidence for association. (B) Manhattan plot of the association results. The plot shows $-\log 10$ marker-wise $p$ values against their genomic base pair position. The red line indicates the genome-wide significance threshold of $5 \times 10^{-8}$. (C) LocusZoom plot for the association between anti-NMDA receptor encephalitis and variants on chromosome 11 in the genomic region from 46.6 to $48.2 \mathrm{Mb}$. A circle represents a genotyped and a plus symbol an imputed variant. The $r^{2}$ metric displays the pairwise LD between the leading and the respective variant. Gene positions are present in the bottom part. (D) LocusZoom plot for associations on chromosome 15 in the genomic region from 100.9 to $101.1 \mathrm{Mb}$.

hampered by the low disease prevalence of anti-NMDAR encephalitis, which is estimated to be around 0.6/100,000 population. ${ }^{2}$ Despite the small sample size, we were able to find 2 distinct genomic regions on chromosomes 11 and 15 harboring genome-wide significant disease-associated variants. We did not identify additional loci containing variants with suggestive $p$ values very close to genome-wide significance. The locus on chromosome 15 encompasses $\sim 100.000$ 
Table 2 Identified Associations With a $p$ Value $<5 \times 10^{-8}$

\begin{tabular}{|c|c|c|c|c|c|c|c|c|}
\hline CHR & BP [GRCh38] & dbSNP ID & MAF affected & MAF control & OR $(95 \% \mathrm{Cl})$ & $p$ Value & IM/GT & Gene \\
\hline 15 & $100,978,492$ & rs10902588 & 0.33 & 0.18 & $2.24(1.70-2.95)$ & $1.18 \mathrm{e}-8$ & IM & LRRK1 \\
\hline 15 & 100985970 & rs2412001 & 0.34 & 0.19 & $2.18(1.66-2.85)$ & $1.39 \mathrm{e}-8$ & IM & LRRK1 \\
\hline 15 & 100996156 & rs4995826 & 0.38 & 0.22 & $2.14(1.64-2.78)$ & $1.53 \mathrm{e}-8$ & IM & LRRK1 \\
\hline 15 & 100996211 & rs4352030 & 0.38 & 0.22 & $2.14(1.64-2.78)$ & $1.53 \mathrm{e}-8$ & IM & LRRK1 \\
\hline 15 & 100996820 & rs966292 & 0.38 & 0.22 & $2.14(1.64-2.78)$ & $1.53 e-8$ & IM & LRRK1 \\
\hline 15 & 100998427 & rs66793839 & 0.38 & 0.22 & $2.14(1.64-2.78)$ & $1.53 \mathrm{e}-8$ & IM & LRRK1 \\
\hline 15 & 100986608 & rs11636885 & 0.32 & 0.18 & $2.19(1.66-2.89)$ & $2.66 \mathrm{e}-8$ & $\mathrm{IM}$ & LRRK1 \\
\hline 15 & 100996725 & rs966293 & 0.32 & 0.18 & $2.19(1.66-2.89)$ & $2.87 e-8$ & GT & LRRK1 \\
\hline 15 & 101000513 & rs55785108 & 0.32 & 0.18 & $2.19(1.66-2.89)$ & $2.87 \mathrm{e}-8$ & IM & LRRK1 \\
\hline 15 & 100980449 & rs12442816 & 0.32 & 0.18 & $2.17(1.65-2.86)$ & $3.60 \mathrm{e}-8$ & IM & LRRK1 \\
\hline 11 & 47244920 & rs75393320 & 0.29 & 0.16 & $2.20(1.66-2.92)$ & $3.78 \mathrm{e}-8$ & IM & ACP2 \\
\hline 11 & 47259211 & rs11039155 & 0.29 & 0.16 & $2.20(1.66-2.92)$ & $3.78 \mathrm{e}-8$ & IM & NR1H3 \\
\hline 15 & 101003755 & rs55759655 & 0.34 & 0.19 & $2.12(1.62-2.78)$ & $3.96 \mathrm{e}-8$ & $\mathrm{IM}$ & LRRK1 \\
\hline
\end{tabular}

Abbreviations: $\mathrm{BP}=$ base-pair gene; dbSNP = database of single nucleotide polymorphisms; $\mathrm{GT}=$ genotyped; IM = imputed; $\mathrm{MAF}=$ minor allele frequency. The top-SNPs at each locus are highlighted in bold, with rs75393320 and rs11039155 on chromosome 11 having the same $p$ value.

bp and contains only 1 gene, LRRK1. Although genetic variants in the homolog leucine rich repeat region 2 (LRRK2) are the most common cause of autosomal dominant Parkinson disease, no neurologic diseases are currently linked to $L R R K 1$. In mice, $L R R K 1$ and $L R R K 2$ complement each other at least partially in the nervous system because only deficiency of both proteins causes a neurodegenerative phenotype and both proteins regulate autophagy. ${ }^{24}$ LRRK1 is expressed in $\mathrm{B}$ cells and monocytes, suggesting a role in the immune system. ${ }^{25}$ Indeed, LRRK1-deficient mice show alterations of B-cell development, failure to produce IgG3 class antibodies in response to non-T-cell dependent antigens, and a proliferation and survival defect on B-cell receptor stimulation. ${ }^{26}$ Yet, there is currently no known connection between LRRK1 and autoimmunity. However, it is intriguing to speculate that LRRK1-mediated control of non-T-cell dependent B-cell activation could be dysregulated in patients with antiNMDAR encephalitis. Indeed, this could explain the observation of frequent nonmutated, germ-line encoded NMDAR antibodies in patients, ${ }^{27}$ the childhood and early adult manifestation, and the coexistence of additional autoantibodies. ${ }^{28}$

The borders of the genomic region on chromosome 11 harboring the second association signal are less defined. The region is much larger, exceeding $1 \mathrm{Mb}$, and comprises multiple genes. To generate a hypothesis concerning putatively causal genes in this region, we used colocalization analysis between eQTL data from GTEx for different brain regions as well as immune cell eQTL from the BLUEPRINT project. In brain tissues, we found evidence for colocalization between the genes $A C P 2$ and $M A D D$ with eQTL for cerebellum and NR1H3 with eQTL for the hypothalamus. Although it is well known that the hippocampus is a prime target of anti-NMDAR encephalitis, the ubiquitous expression of NMDA receptors containing the GluN1 subunit in the brain, the manifold symptoms of antiNMDAR encephalitis, and pathologic studies suggest an involvement of most if not all brain regions. ${ }^{29}$ Therefore, we think that the cerebellum and hypothalamus are valid target regions. In immune cells, we detected colocalization of the genes NR1H3, ACP2, DDB2, and C11orf49 with eQTL in various immune cells including T-lymphocytes. NR1H3 and ACP2 show evidence for colocalization in both brain and immune cells. Unfortunately, B-lymphocytes/plasma cells, the producers of antibodies, are not represented in the BLUEPRINT data. Of the genes identified in the colocalization analysis, $N R 1 H 3$ encoding the liver $\mathrm{X}$ receptor alpha (LXR $\alpha$ ) is the best functional candidate. LXR $\alpha$ is a transcription factor whose activation inhibits inflammatory processes. ${ }^{30}$ In the CNS, LXR $\alpha$ agonists inhibit proinflammatory cytokine production by microglia and astrocytes. ${ }^{31}$ Knockout of LXR $\alpha$ in brain endothelial cells led to blood-brain barrier dysfunction, inflammation, and increased transendothelial mononuclear cell migration. ${ }^{32}$ ACP2 is a lysosomal acid phosphatase used in lysosomal protein degradation, MADD is an adaptor protein involved in transmitting tumor necrosis factor alpha (TNF- $\alpha$ )-induced apoptotic signals, DDB2 is involved in DNA repair, e.g., after ultraviolet light damage, and C11orf49 encodes a protein of unknown function. 


\begin{tabular}{|c|c|c|c|c|c|c|c|}
\hline & & & ACP2 & NR1H3 & \multicolumn{2}{|c|}{ MADD } & \\
\hline & & $\begin{array}{r}\text { PP4 } \\
\text { \# SNPS }\end{array}$ & $\begin{array}{l}0.91 \\
366\end{array}$ & $\begin{array}{l}0.72 \\
405\end{array}$ & $\begin{array}{l}0.89 \\
502\end{array}$ & $\begin{array}{l}0.89 \\
502\end{array}$ & \\
\hline & $3.4 \mathrm{e}-07$ & rs830085 & 0.17 & 0.01 & 0.01 & 0.01 & \\
\hline & $3.5 e-07$ & rs7129661 & 0.03 & 0.02 & 0.00 & 0.00 & \\
\hline & $3.5 e-07$ & rs7120118 & 0.07 & 0.03 & 0.00 & 0.00 & \\
\hline & $3.5 e-07$ & rs6485746 & 0.07 & 0.02 & 0.00 & 0.00 & \\
\hline & $3.5 e-07$ & rs59663860 & 0.07 & 0.02 & 0.00 & 0.00 & \\
\hline & $3.5 e-07$ & rs4752822 & 0.07 & 0.02 & 0.00 & 0.00 & \\
\hline & $3.5 e-07$ & rs3758673 & 0.07 & 0.02 & 0.00 & 0.00 & \\
\hline & $3.5 \mathrm{e}-07$ & rs3758672 & 0.07 & 0.01 & 0.00 & 0.00 & \\
\hline & $35 \mathrm{e}-07$ & rs3758669 & 0.07 & 0.02 & 0.00 & 0.00 & \\
\hline & $3.5 \mathrm{e}-0 / 1$ & rs35879051 & 0.07 & 0.02 & 0.00 & 0.00 & \\
\hline & $3.5 \mathrm{e}-0 /$ & rs2279239 & 0.07 & 0.02 & 0.00 & 0.00 & \\
\hline & $3.5 \mathrm{e}-07$ & rs2013867 & 0.03 & 0.02 & 0.00 & 0.00 & \\
\hline & $4.0 \mathrm{e}-07$ & rs901746 & 0.01 & 0.04 & 0.00 & 0.00 & \\
\hline & $4.0 \mathrm{e}-07$ & rs7395581 & 0.07 & 0.02 & 0.00 & 0.00 & \\
\hline & $4.0 e-07$ & rs7109203 & 0.01 & 0.03 & 0.00 & 0.00 & \\
\hline & 4.0e-07 & rs11039156 & 0.01 & 0.04 & 0.00 & 0.00 & \\
\hline & 4.0e-07 & rs10838684 & 0.01 & 0.03 & 0.00 & 0.00 & \\
\hline & 5.0e-07 & rs326222 & 0.01 & 0.01 & 0.00 & 0.00 & \\
\hline & $5.1 \mathrm{e}-07$ & rs2167079 & 0.00 & 0.03 & 0.00 & 0.00 & \\
\hline & $5.1 \mathrm{e}-07$ & rs7940809 & 0.00 & 0.01 & 0.04 & 0.04 & \\
\hline & $5.1 \mathrm{e}-07$ & rs7127907 & 0.00 & 0.01 & 0.02 & 0.03 & \\
\hline & $5.1 e-07$ & rs61896050 & 0.00 & 0.01 & 0.04 & 0.04 & \\
\hline$p$ value GWAS & $5.1 e-07$ & rs4752825 & 0.00 & 0.01 & 0.04 & 0.04 & $\begin{array}{l}\text { Posterior } \\
\text { probability }\end{array}$ \\
\hline $1.7 e-07$ & $5.1 e-07$ & rs4752824 & 0.00 & 0.01 & 0.03 & 0.03 & probability \\
\hline & $5.1 \mathrm{e}-07$ & rs3847502 & 0.00 & 0.01 & 0.04 & 0.04 & 1 \\
\hline & $5.1 \mathrm{e}-07$ & rs3816725 & 0.00 & 0.01 & 0.04 & 0.03 & \\
\hline $3.4 \mathrm{e}-07$ & $5.1 \mathrm{e}-07$ & rs3781622 & 0.00 & 0.01 & 0.04 & 0.04 & 0 \\
\hline & $5.1 \mathrm{e}-07$ & rs3781621 & 0.00 & 0.01 & 0.04 & 0.04 & \\
\hline & $5.1 \mathrm{e}-07$ & rs1449627 & 0.00 & 0.01 & 0.04 & 0.06 & \\
\hline & 5.1e-07 & rs1375688 & 0.00 & 0.01 & 0.04 & 0.04 & \\
\hline & 5.1e-07 & rs12575456 & 0.00 & 0.01 & 0.04 & 0.04 & \\
\hline & $5.1 \mathrm{e}-07$ & rs11039166 & 0.00 & 0.01 & 0.04 & 0.04 & \\
\hline & $5.1 \mathrm{e}-07$ & rs10838692 & 0.00 & 0.01 & 0.04 & 0.04 & \\
\hline & 5.1e-07 & rs10838690 & 0.00 & 0.01 & 0.04 & 0.07 & \\
\hline & $\frac{210-07}{3}$ & rs10742799 & 0.00 & 0.01 & 0.04 & 0.04 & \\
\hline & $5.1 \mathrm{e}-07$ & rs1055510 & 0.00 & 0.01 & 0.04 & 0.04 & \\
\hline & 5.6e-07 & rs10769252 & 0.00 & 0.01 & 0.04 & 0.04 & \\
\hline & 5.6e-07 & rs1052373 & 0.00 & 0.01 & 0.04 & 0.04 & \\
\hline & $5.7 \mathrm{e}-07$ & rs7124955 & 0.00 & 0.03 & 0.02 & 0.00 & \\
\hline & $5.7 \mathrm{e}-07$ & rs7109147 & 0.00 & 0.01 & 0.03 & 0.01 & \\
\hline & $5.7 \mathrm{e}-07$ & rs4752980 & 0.00 & 0.03 & 0.02 & 0.00 & \\
\hline & $5.7 e-07$ & rs11039167 & 0.00 & 0.03 & 0.02 & 0.06 & \\
\hline & $5.7 e-07$ & rs10838693 & 0.00 & 0.03 & 0.02 & 0.00 & \\
\hline & $5.7 e-07$ & rs10838691 & 0.00 & 0.02 & 0.02 & 0.02 & \\
\hline & $5.7 e-07$ & rs10742801 & 0.00 & 0.02 & 0.03 & 0.01 & \\
\hline & $5.7 e-07$ & rs10501321 & 0.00 & 0.03 & 0.02 & 0.00 & \\
\hline & $7.1 \mathrm{e}-07$ & rs326214 & 0.00 & 0.01 & 0.03 & 0.00 & \\
\hline & & & ' & 1 & ' & ' & \\
\hline
\end{tabular}

Gene- and SNP-wise results of the colocalization analysis for brain tissues represented in Genotype-Tissue Expression types. Only genes with a PP4 > 0.7 and variants with a $p$ value $<10^{-5}$ are shown. $A C P 2=$ acid phosphatase 2 , lysosomal; GWAS = genome-wide association study; MADD = mitogen-activated protein kinase activating death domain; NR1 H3 = nuclear receptor subfamily 1 group $\mathrm{H}$ member 3.

In contrast to our first GWAS of antibody-mediated encephalitis, we identified 2 independent genome-wide significant associations in this study. There are 3 important differences between our previous GWAS and the current one. First, doubling of the sample size led to larger statistical power; second, we carefully removed population outliers; and third, we chose a different set of covariates in the logistic regression model. In contrast to the first GWAS, we included only sex and the first PC in the current analysis. Scree plot analysis suggested using only $1 \mathrm{PC}$, which might in part be due to the stringent exclusion of ethnic outliers and careful control matching. Another difference to the first GWAS is 


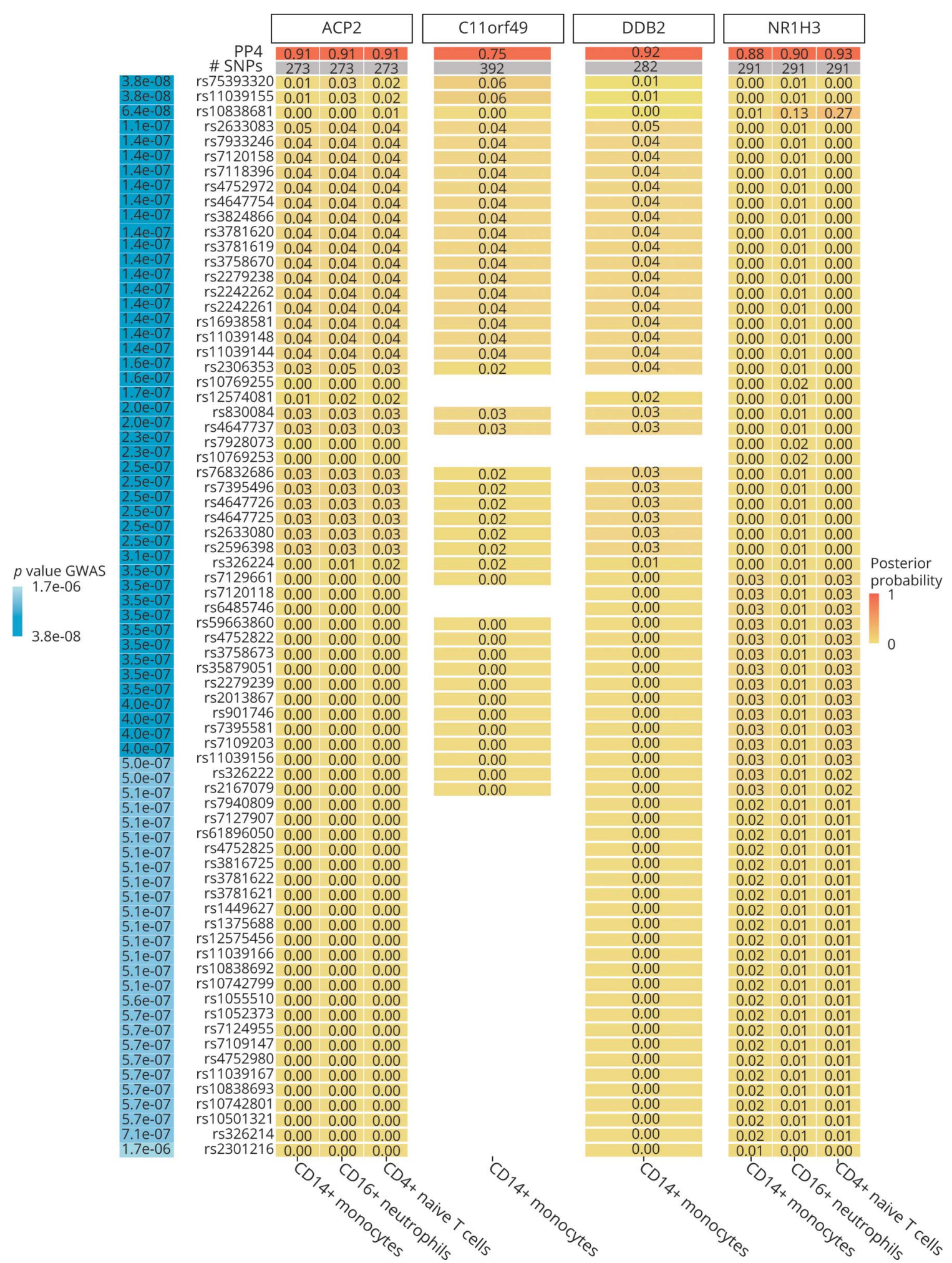

Gene- and SNP-wise results of the colocalization for immune cells represented in the BLUEPRINT data set. Only genes with a PP4 $>0.7$ and variants with a $p$ value $<10^{-5}$ are shown. ACP2 = acid phosphatase 2, lysosomal; C11 orf49 = chromosome 11 open reading frame 49; DDB2 = damage-specific DNA binding protein 2; GWAS = genome-wide association study; NR1H3 = nuclear receptor subfamily 1 group H member 3.

the exclusion of age as a covariate. Genetic variants are stable throughout life. For common late-onset diseases, significantly younger controls than patients warrant inclusion of age as a covariate because many controls will still develop the disease during their lifetime. However, in this study, the disease is rare, and the controls are significantly older than 
the patients. Including age as a covariate led to partial masking of the signals contributing to the effects in this GWAS. The major shortcoming of this study is its small sample size, which on the one hand limits the power to detect true variant-disease associations and on the other hand did not allow to include an independent replication sample, thereby increasing the likelihood of false positives. In our opinion, increasing the sample size by international cooperation as well as locus fine-mapping by sequencing and analysis of multiethnic samples will be key in future studies. The history of GWAS has shown that in most diseases, increasing sample size was more important than more detailed phenotyping. This might be particularly true in antibodymediated encephalitis because the antigen specificity itself leads to a rather homogenous biologic disease entity compared with most other neurologic diseases, e.g., polygenic neurodegenerative disorders. In summary, we performed a GWAS of anti-NMDA receptor encephalitis and identified 2 independent genome-wide significant association signals. Both genomic regions contain putative functional candidate genes. In addition, eQTL for 5 genes show significant colocalization with the association signal on chromosome 11.

\section{Acknowledgment}

The work was supported by members of the GENERATE network, who contributed to patient recruitment, data acquisition, and entry. All members of the GENERATE network as of March 2021 are indicated in eTable 1, links.lww. com/NXI/A587. Patient recruitment in the Czech Republic was supported by the Charles University project GA UK No. 746120. Petr Marusic (Department of Neurology, Charles University, Second Faculty of Medicine, and Motol University Hospital, Prague, Czech Republic) helped with patient selection and clinical data collection for the Czech participants. The popgen 2.0 network ( $\mathrm{P} 2 \mathrm{~N}$; controls) is supported by the Medical Faculty of the University of Kiel. The Genotype-Tissue Expression (GTEx) Project was supported by the Common Fund of the Office of the Director of the National Institutes of Health and by NCI, NHGRI, NHLBI, NIDA, NIMH, and NINDS. The data used for the analyses described in this article were obtained from $\mathrm{dbGaP}$ accession number phs000424.v7.p2.

\section{Study Funding}

This work was in part funded by the Federal Ministry of Education and Research (BMBF) through a grant to F.L. and G.K. within the scope of the project CONNECT-GENERATE, grant code 01GM1908A.

\section{Disclosure}

The authors report no disclosures relevant to the manuscript. Go to Neurology.org/NN for full disclosures.

\section{Publication History}

Received by Neurology: Neuroimmunology \& Neuroinflammation March 16, 2021. Accepted in final form July 9, 2021.

\section{Appendix 1 Authors}

\begin{tabular}{|c|c|c|}
\hline Name & Location & Contribution \\
\hline $\begin{array}{l}\text { Anja K. Tietz, } \\
\text { MSc }\end{array}$ & Kiel University, Kiel, Germany & $\begin{array}{l}\text { Acquisition and analysis } \\
\text { of the data; drafted the } \\
\text { manuscript; and } \\
\text { revised the final } \\
\text { manuscript }\end{array}$ \\
\hline
\end{tabular}

\begin{tabular}{lll}
\hline $\begin{array}{l}\text { Klemens } \\
\text { Angstwurm, MD }\end{array}$ & $\begin{array}{l}\text { University Hospital } \\
\text { Regensburg, Regensburg, } \\
\text { Germany }\end{array}$ & $\begin{array}{l}\text { Major role in the } \\
\text { acquisition of data and } \\
\text { revised the final } \\
\text { manuscript }\end{array}$ \\
$\begin{array}{l}\text { Tobias } \\
\text { Baumgartner, } \\
\text { MD }\end{array}$ & $\begin{array}{l}\text { University Hospital Bonn, } \\
\text { Bonn, Germany }\end{array}$ & $\begin{array}{l}\text { Major role in the } \\
\text { acquisition of data and } \\
\text { revised the final } \\
\text { manuscript }\end{array}$ \\
$\begin{array}{l}\text { Kathrin } \\
\text { Doppler, MD }\end{array}$ & $\begin{array}{l}\text { University Hospital Würzburg, } \\
\text { Würburg, Germany }\end{array}$ & $\begin{array}{l}\text { Major role in the } \\
\text { acquisition of data and } \\
\text { revised the final } \\
\text { manuscript }\end{array}$ \\
\hline
\end{tabular}

\begin{tabular}{lll}
\hline $\begin{array}{l}\text { Katharina } \\
\text { Eisenhut, MD }\end{array}$ & $\begin{array}{l}\text { Biomedical Center and } \\
\text { University Hospital, Ludwig } \\
\text { Maximilians University, } \\
\text { Munich, Germany }\end{array}$ & $\begin{array}{l}\text { Major role in the } \\
\text { acquisition of data and } \\
\text { revised the final } \\
\text { manuscript }\end{array}$ \\
$\begin{array}{l}\text { Martin Elisak, } \\
\text { MD }\end{array}$ & $\begin{array}{l}\text { Charles University and Motol } \\
\text { University Hospital, Prague, } \\
\text { Czech Republic }\end{array}$ & $\begin{array}{l}\text { Major role in the } \\
\text { acquisition of data and } \\
\text { revised the final } \\
\text { manuscript }\end{array}$ \\
\hline
\end{tabular}

Andre Franke, Kiel University, Kiel, Germany Major role in the PhD acquisition of data and revised the final manuscript

\begin{tabular}{|c|c|c|}
\hline $\begin{array}{l}\text { Kristin S. } \\
\text { Golombeck, MD }\end{array}$ & $\begin{array}{l}\text { University Hospital Münster, } \\
\text { Münster, Germany }\end{array}$ & $\begin{array}{l}\text { Major role in the } \\
\text { acquisition of data and } \\
\text { revised the final } \\
\text { manuscript }\end{array}$ \\
\hline $\begin{array}{l}\text { Robert } \\
\text { Handreka }\end{array}$ & $\begin{array}{l}\text { Carl-Thiem-Klinikum Cottbus, } \\
\text { Cottbus, Germany }\end{array}$ & $\begin{array}{l}\text { Major role in the } \\
\text { acquisition of data and } \\
\text { revised the final } \\
\text { manuscript }\end{array}$ \\
\hline $\begin{array}{l}\text { Max Kaufmann, } \\
\text { MD }\end{array}$ & $\begin{array}{l}\text { University Medical Center } \\
\text { Hamburg-Eppendorf, } \\
\text { Hamburg, Germany }\end{array}$ & $\begin{array}{l}\text { Major role in the } \\
\text { acquisition of data and } \\
\text { revised the final } \\
\text { manuscript }\end{array}$ \\
\hline $\begin{array}{l}\text { Markus } \\
\text { Kraemer, MD }\end{array}$ & $\begin{array}{l}\text { Alfried Krupp Hospital, Essen } \\
\text { and Heinrich-Heine University } \\
\text { Düsseldorf, Düsseldorf, } \\
\text { Germany }\end{array}$ & $\begin{array}{l}\text { Major role in the } \\
\text { acquisition of data and } \\
\text { revised the final } \\
\text { manuscript }\end{array}$ \\
\hline $\begin{array}{l}\text { Andrea Kraft, } \\
\text { MD }\end{array}$ & $\begin{array}{l}\text { Martha-Maria Hospital Halle, } \\
\text { Halle, Germany }\end{array}$ & $\begin{array}{l}\text { Major role in the } \\
\text { acquisition of data and } \\
\text { revised the final } \\
\text { manuscript }\end{array}$ \\
\hline $\begin{array}{l}\text { Jan Lewerenz, } \\
\text { MD }\end{array}$ & $\begin{array}{l}\text { University of Ulm, Ulm, } \\
\text { Germany }\end{array}$ & $\begin{array}{l}\text { Major role in the } \\
\text { acquisition of data and } \\
\text { revised the final } \\
\text { manuscript }\end{array}$ \\
\hline $\begin{array}{l}\text { Wolfgang Lieb, } \\
\text { MD }\end{array}$ & Kiel University, Kiel, Germany & $\begin{array}{l}\text { Major role in the } \\
\text { acquisition of data and } \\
\text { revised the final } \\
\text { manuscript }\end{array}$ \\
\hline $\begin{array}{l}\text { Marie } \\
\text { Madlener, MD }\end{array}$ & $\begin{array}{l}\text { University Hospital Cologne, } \\
\text { Cologne, Germany }\end{array}$ & $\begin{array}{l}\text { Major role in the } \\
\text { acquisition of data and } \\
\text { revised the final } \\
\text { manuscript }\end{array}$ \\
\hline
\end{tabular}


Appendix 1 (continued)

\begin{tabular}{lll}
\hline Name & Location & Contribution \\
\hline Nico Melzer, MD & $\begin{array}{l}\text { Heinrich-Heine University } \\
\text { Düsseldorf, Düsseldorf, } \\
\text { Germany }\end{array}$ & $\begin{array}{l}\text { Major role in the } \\
\text { acquisition of data and } \\
\text { revised the final } \\
\text { manuscript }\end{array}$ \\
\hline $\begin{array}{l}\text { Hana } \\
\text { Mojzisova, MD }\end{array}$ & $\begin{array}{l}\text { Charles University and Motol } \\
\text { Czech Republic }\end{array}$ & $\begin{array}{l}\text { Major role in the } \\
\text { acquisition of data and } \\
\text { revised the final } \\
\text { manuscript }\end{array}$ \\
\hline $\begin{array}{l}\text { Peter Möller, } \\
\text { MD }\end{array}$ & $\begin{array}{l}\text { Klinikum Weimar, Weimar, } \\
\text { Germany }\end{array}$ & $\begin{array}{l}\text { Major role in the } \\
\text { acquisition of data and } \\
\text { revised the final } \\
\text { manuscript }\end{array}$ \\
& &
\end{tabular}

\begin{tabular}{lll}
\hline Thomas & Klinikum Ingolstadt, & Major role in the \\
Pfefferkorn, MD & Ingolstadt, Germany & $\begin{array}{l}\text { acquisition of data and } \\
\text { revised the final } \\
\end{array}$ \\
& manuscript
\end{tabular}

\begin{tabular}{lll}
\hline Harald Prüss, & Charité-Universitätsmedizin & Major role in the \\
MD & Berlin and German Center & acquisition of data and \\
& for Neurodegenerative & revised the final \\
& $\begin{array}{l}\text { Diseases (DZNE) Berlin, } \\
\text { Berlin, Germany }\end{array}$ & manuscript
\end{tabular}

\begin{tabular}{ll}
\hline Kevin Rostásy, & Children's Hospital Datteln, \\
MD & Witten/Herdecke University, \\
& Datteln, Germany
\end{tabular}

Major role in the acquisition of data and revised the final manuscript

\begin{tabular}{lll}
\hline $\begin{array}{l}\text { Margret } \\
\text { Schnegelsberg, } \\
\text { MD }\end{array}$ & $\begin{array}{l}\text { Asklepios Hospitals } \\
\text { Schildautal, Seesen, Germany }\end{array}$ & $\begin{array}{l}\text { Major role in the } \\
\text { acquisition of data and } \\
\text { revised the final } \\
\text { manuscript }\end{array}$ \\
\hline Ina Schröder & $\begin{array}{l}\text { University Hospital Schleswig- } \\
\text { Holstein, Kiel/Lübeck, } \\
\text { Germany }\end{array}$ & $\begin{array}{l}\text { Major role in the } \\
\text { acquisition of data and } \\
\text { revised the final } \\
\text { manuscript }\end{array}$
\end{tabular}

\begin{tabular}{ll}
\hline Kai & Unversity Hospital and \\
Siebenbrodt, & Goethe Universiy Frankfurt, \\
MD & Frankfurt am Main, Germany
\end{tabular}

Major role in the acquisition of data and revised the final manuscript

Kurt-Wolfram Hannover Medical School,

Major role in the Sühs, MD Hannover, Germany acquisition of data and
revised the final manuscript

\begin{tabular}{|c|c|c|}
\hline $\begin{array}{l}\text { Jonathan } \\
\text { Wickel, MD }\end{array}$ & $\begin{array}{l}\text { University Hospital Jena, Jena, } \\
\text { Germany }\end{array}$ & $\begin{array}{l}\text { Major role in the } \\
\text { acquisition of data anc } \\
\text { revised the final } \\
\text { manuscript }\end{array}$ \\
\hline $\begin{array}{l}\text { Klaus-Peter } \\
\text { Wandinger, MD }\end{array}$ & $\begin{array}{l}\text { University Hospital Schleswig- } \\
\text { Holstein, Kiel/Lübeck, } \\
\text { Germany }\end{array}$ & $\begin{array}{l}\text { Major role in the } \\
\text { acquisition of data } \\
\text { and revised the final } \\
\text { manuscript }\end{array}$ \\
\hline
\end{tabular}

Frank Leypoldt, University Hospital Schleswig- Conceptualized the MD Holstein, Kiel/Lübeck and Kiel study; acquisition University, Kiel, Germany and interpretation of the data; and revised the final manuscript

\begin{tabular}{|c|c|c|}
\hline $\begin{array}{l}\text { Gregor } \\
\text { Kuhlenbäumer, } \\
\text { MD, PhD }\end{array}$ & Kiel University, Kiel, Germany & $\begin{array}{l}\text { Conceptualized the } \\
\text { study; drafted the } \\
\text { manuscript; analysis } \\
\text { and interpretation } \\
\text { of the data; and } \\
\text { revised the final } \\
\text { manuscript }\end{array}$ \\
\hline
\end{tabular}

\section{Appendix 2 Coinvestigators}

Coinvestigators are listed in Appendix 2 at links.Iww.com/NXI/A587.

\section{References}

1. Dalmau J, Armangué T, Planagumà J, et al. An update on anti-NMDA receptor encephalitis for neurologists and psychiatrists: mechanisms and models. Lancet Neurol. 2019;18(11):1045-1057.

2. Dubey D, Pittock SJ, Kelly CR, et al. Autoimmune encephalitis epidemiology and a comparison to infectious encephalitis. Ann Neurol. 2018;83(1):166-177.

3. Graus F, Titulaer MJ, Balu R, et al. A clinical approach to diagnosis of autoimmune encephalitis. Lancet Neurol. 2016;15(4):391-404.

4. Mueller SH, Färber A, Prüss H, et al. Genetic predisposition in anti-LGIl and antiNMDA receptor encephalitis. Ann Neurol. 2018;83(4):863-869.

5. Nothlings U, Krawczak M, PopGen. A population-based biobank with prospective follow-up of a control group. Bundesgesundheitsblatt Gesundheitsforschung Gesundheitsschutz. 2012;55(6-7):831-835.

6. Krawczak M, Nikolaus S, von Eberstein H, Croucher PJ, El Mokhtari NE, Schreiber S PopGen: population-based recruitment of patients and controls for the analysis of complex genotype-phenotype relationships. Community Genet. 2006;9(1):55-61.

7. Purcell S, Neale B, Todd-Brown K, et al. PLINK: a tool set for whole-genome association and population-based linkage analyses. Am J Hum Genet. 2007;81(3):559-575.

8. R Core Team. R: A Language and Environment for Statistical Computing. R Foundation for Statistical Computing; 2020.

9. Meyer HV. plinkQC: Genotype Quality Control in Genetic Association Studies; 2020.

10. 1000 Genomes Project Consortium. A global reference for human genetic variation. Nature. 2015;526(7571):68.

11. Brown DW, Myers TA, Machiela MJ. PCAmatchR: a flexible R package for optimal case-control matching using weighted principal components. Bioinformatics 2020 .

12. Taliun D, Harris DN, Kessler MD, et al. Sequencing of 53,831 diverse genomes from the NHLBI TOPMed Program. Nature. 2021;590(7845):290-299.

13. Das S, Forer L, Schönherr S, et al. Next-generation genotype imputation service and methods. Nat Genet. 2016;48(10):1284-1287.

14. Fuchsberger C, Abecasis GR, Hinds DA. minimac2: faster genotype imputation. Bioinformatics. 2015;31(5):782-784.

15. Cattell RB. The scree test for the number of factors. Multivariate Behav Res. 1966; 1(2):245-276

16. Zheng J, Erzurumluoglu AM, Elsworth BL, et al. LD Hub: a centralized database and web interface to perform LD score regression that maximizes the potential of summary level GWAS data for SNP heritability and genetic correlation analysis. Bioinformatics. 2017;33(2):272-279.

17. Zheng X, Shen J, Cox C, et al. HIBAG-HLA genotype imputation with attribute bagging. Pharmacogenomics J. 2014;14(2):192-200

18. Fan Y, Song YQ. PyHLA: tests for the association between HLA alleles and diseases. BMC Bioinformatics. 2017;18(1):90-95.

19. GTEx Consortium. Genetic effects on gene expression across human tissues. Nature. 2017;550(7675):204.

20. Chen L, Ge B, Casale FP, et al. Genetic drivers of epigenetic and transcriptional variation in human immune cells. Cell. 2016;167(5):1398.e24-1414.e24.

21. Giambartolomei C, Vukcevic D, Schadt EE, et al. Bayesian test for colocalisation between pairs of genetic association studies using summary statistics. Plos Genet. 2014; 10(5):e1004383.

22. Pruim RJ, Welch RP, Sanna S, et al. LocusZoom: regional visualization of genomewide association scan results. Bioinformatics. 2010;26(18):2336-2337.

23. Shu YQ, Qiu W, Zheng JF, et al. HLA class II allele DRB1*16:02 is associated with anti-NMDAR encephalitis. J Neurol Neurosur Psychiatry. 2019;90(6):652-658.

24. Giaime E, Tong Y, Wagner LK, Yuan Y, Huang G, Shen J. Age-dependent dopaminergic neurodegeneration and impairment of the autophagy-lysosomal pathway in LRRK-deficient mice. Neuron. 2017;96(4):796-e6.

25. Thévenet J, Pescini Gobert R, Hooft van Huijsduijnen R, Wiessner C, Sagot YJ Regulation of LRRK2 expression points to a functional role in human monocyte maturation. PLoS One. 2011;6(6):e21519.

26. Morimoto K, Baba Y, Shinohara H, et al. LRRK1 is critical in the regulation of B-cell responses and CARMA1-dependent NF- $\mathrm{B}$ activation. Sci Rep. 2016;6(1):25738-25813.

27. Wenke NK, Kreye J, Andrzejak E, et al. N-methyl-D-aspartate receptor dysfunction by unmutated human antibodies against the NR1 subunit. Ann Neurol. 2019;85(5):771-776.

28. Martinez-Hernandez E, Guasp M, Garcia-Serra A, et al. Clinical significance of antiNMDAR concurrent with glial or neuronal surface antibodies. Neurology. 2020; 94(22):e2302-e2310.

29. Hirano M, Itoh T, Fujimura $\mathrm{H}$, et al. Pathological findings in male patients with anti-Nmethyl-D-Aspartate receptor encephalitis. J Neuropathol Exp Neurol. 2019;78(8):735-741.

30. Zhao L, Lei W, Deng C, et al. The roles of liver X receptor $\alpha$ in inflammation and inflammation-associated diseases. J Cell Physiol 2020.

31. Zhang-Gandhi CX, Drew PD. Liver X receptor and retinoid X receptor agonists inhibit inflammatory responses of microglia and astrocytes. J Neuroimmunol. 2007; 183(1-2):50-59.

32. Wouters E, de Wit NM, Vanmol J, et al. Liver X receptor alpha is important in maintaining blood-brain barrier function. Front Immunol. 2019;10:1811. 


\title{
Neurology \\ Neuroimmunology \& Neuroinflammation
}

\author{
Genome-wide Association Study Identifies 2 New Loci Associated With Anti-NMDAR \\ Encephalitis \\ Anja K. Tietz, Klemens Angstwurm, Tobias Baumgartner, et al. \\ Neurol Neuroimmunol Neuroinflamm 2021;8; \\ DOI 10.1212/NXI.0000000000001085
}

This information is current as of September 28, 2021

Updated Information \&

Services

References

Subspecialty Collections

Permissions \& Licensing

Reprints including high resolution figures, can be found at:

http://nn.neurology.org/content/8/6/e1085.full.html

This article cites 28 articles, 1 of which you can access for free at: http://nn.neurology.org/content/8/6/e1085.full.html\#\#ref-list-1

This article, along with others on similar topics, appears in the following collection(s):

Association studies in genetics

http://nn.neurology.org//cgi/collection/association_studies_in_genetics Autoimmune diseases

http://nn.neurology.org//cgi/collection/autoimmune_diseases

Information about reproducing this article in parts (figures,tables) or in its entirety can be found online at:

http://nn.neurology.org/misc/about.xhtml\#permissions

Information about ordering reprints can be found online:

http://nn.neurology.org/misc/addir.xhtml\#reprintsus

Neurol Neuroimmunol Neuroinflamm is an official journal of the American Academy of Neurology.

Published since April 2014, it is an open-access, online-only, continuous publication journal. Copyright

Copyright (C) 2021 The Author(s). Published by Wolters Kluwer Health, Inc. on behalf of the American

Academy of Neurology.. All rights reserved. Online ISSN: 2332-7812.

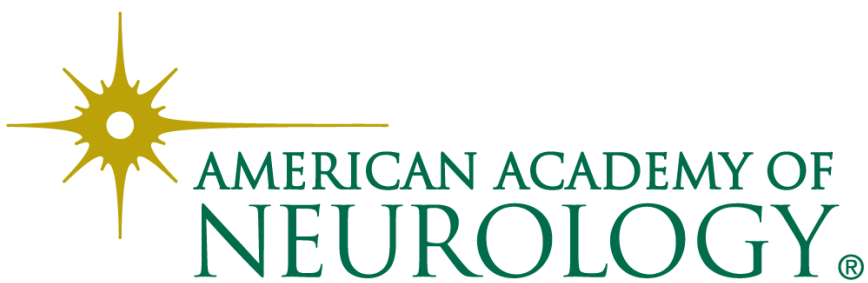

